\title{
RIPARIAN VEGETATION OF THE NORTHERN RANGE, YELLOWSTONE NATIONAL PARK; CLASSIFICATION, SUCCESSION, AND ENVIR ONMENTAL RELATIONSHIPS
}

\author{
Robert D. Pfister \\ Stephen V. Cooper \\ Montana Forest and Conservation Experiment Station \\ University of Montana \\ Missoula
}

\section{Objectives}

The primary objective of the 1985 field season was to acquire a sufficient number of wetland vegetation samples (plots) from across the range of environments present on the northern range (elk winter range) of Yellowstone National Park (YNP) to permit community and gradient analysis of these wetlands. These plots will contribute toward our first product, a wetlands community type classification suitable for management applications such as vegetation mapping and interpretation.

Two equally important objectives, but ones necessarily temporally following the above objective, are (1) elucidation of the causal factors and/or quantification of the associated environmental factors for each vegetation type, (2) illustration of the relationships among vegetation types along environmental gradients and the most probable successional pathways between successional stages. Such basic knowledge about these wetlands is necessary to their sound management. Wildland managers have a fundamental interest in predicting both short- and long-term vegetation trends because of the importance of vegetation to animal populations.

\section{Methods}

Methodology outlined below is directed to achieving only the above-stated first year study, goals. Examining color aerial photos in conjunction with a topographic map with the northern range delineated we noted potential wetlands throughout the geographical extent of the area. Sampling of these selected areas was also non-random, choosing sites for their accessibility and maximum diversity of communities (and environments) in a circumscribed area.

Plots were located in plant communities judged homogeneous, largely on the basis of dominance by layers. Sample plot size $(50 \mathrm{~m})$ conforms to that commonly employed in wetland studies where environmental gradients are steep. Daubenmire's (1959) cover classes were used to estimate canopy coverage by species. Abiotic site variables recorded included elevation, slope, aspect, parent material, soil conditions (particularly organic horizon nature and depth), and depth and distance to water. Observations were made on animal (ungulate) use and disturbance (current and historical). Second phase sampling will include 
those factors most probably correlated with wetland com munity types, especially water chemistry ( $\mathrm{pH}$, conductivity, redox potential, water color (spectral absorbtion), certain nutrients) and water table seasonal fluctuations.

Species canopy coverage estimates enable us to key each plot through existing regional (Mattson (1984) Solfatara Plateau of YNP, Youngblood and others (1985) eastern Idaho-western Wyoming, Pierce (1985) west-central Montana) as well as national wetland classifications (Cowardin and others (1979). These classifications and associated descriptions represent state-of-knowledge of regional wetlands ecology. If our plots key to described types and the ecological conditions match, then we could progress rapidly to the study's next phase. Whether or not our plots fit published classifications our data will be processed through PHYSIS, an interactive computer program for constructing association tables and computing similarity values and cluster analyses, DECORANA, a program producing simultaneous species and sample ordinations, and TWINSPAN, a divisive polythetic clustering algorithm.

\section{Preliminary Results}

This study is currently at the descriptive-classificatory stage. Two hundred reconnaissance level plots were sampled in the 1985 field season. Referencing our plots to the national wetlands-deepwater classification of Cowardin and others (1979) all would be included in the Palustrine System (most inclusive level), which treats all nontidal wetlands dominated by trees, shrubs, persistent emergents, and emergent mosses or lichens. At the class level, describing the general appearance of the habitat in terms of either dominant life form of the vegetation or substrate physiography and composition, lack of definivive wording in the key did not permit unambiguous identification. However, roughly 28 of the plots were categorized as Forested Wetland, $12 \%$ as Scrub-shrub Wetland, and the remaining $86 \%$ as Emergent Wetland. Finer distinctions in life form are recognized at the subclass level. Within the Forested Wetland class only the Broadleaved Deciduous subclass was sampled. Needle-leaved Evergreen Forested Wetlands are represented but should be adequately handled in a recent forest habitat types classification (Steele and others 1983). Within Scrub-shrub Wetland all samples were described by the Broad-leaved Deciduous subclass. The Emergent Wetland class is divided into subclasses; (1) Persistent, dominated by species that remain standing until the beginning of next season, and (2) Nonpersistent, dominated by plants falling to the substrate or below the water surface. Without second season sampling we can only estimate, based on species' morphological characteristics, that $90 \%$ or more of study area Emergent Wetlands are Persistent.

The taxonomic category subordinate to subclass, dominance type, is determined and named on the basis of dominant plant species, that is, the species that has control over the community and is usually also predominant. Assessing dominance on coverage class and life form we identified at least 56 dominance types (see appendix A). However, four of these types, Carex rostrata, C. rostrata-C. aquatilis, and Juncus balticus, are represented by more than $\overline{80}$ plots, leaving less than 120 plots scattered across 52 dominance types. Thus, at this time many dominance types are represented by a single plot. 
Referencing plots to a national classification offers little insight into specific ecological characteristics and processes such as provided in regional classifications. There were 74,26 , and 13 percent no-fits (plots not keying to a described type) respectively, employing the classifications of Mattson (1984), Youngblood and others (1985), and Pierce (1985). A no-fit designation can be reached at several taxonomic levels, the series, habitat type (community type), or phase. Mattson's Solfatara Plateau classification produced the most no-fits (regardless of taxonomic level) because (1) it was fine-tuned to a very limited and environmentally somewhat different area that lacked the diversity of the northern range, (2) the Solfatara Plateau is more removed from sources of a weedy fllora and man has not tried to manage vegetation, thus disturbance types are lacking, (3) the key was narrowly worded at all levels thus not accommodating variations in coverages of certain crucial species.

No-fits generated by the classification of Youngblood and others (1985) were confined to our communities with persistent standing water, high degree of seasonal watertable flux, or Salix spp. or weedy species dominance. Youngblood and others state explicitly that most emergent communities were beyond their scope. However, this approach would neglect some of the most extensive, productive, and important of the northern range's wetlands.

Though Pierce's (1985) work centers on a geographically removed area, west-central Montana, fewer no-fits were found than with other regional systems. This result points up the broad range and ecological amplitude of many of the wetland species, numerous ones being circumboreal. In fact, many northern range wetland communities have been more completely described (vegetation and apparent ecological relationships) in reports regarding the prairie potholes region of North Dakota (Stewart and Kantrud 1972) than they have been in publications for the areas immediately surrounding the northern range. Concurrent work in the Montana Riparian Cooperative during the coming year will provide the opportuity to compare northern range communities with several locations in Montana.

In terms of classical vegetation type categories we have inventoried environments as diverse as those with soils remaining dry through most of the growing season, supporting range type communities dominated by Potentilla fruticosa and Artemisia cana to those dominated by floating and quaking sedge (Carex spp.) mats (fens) to those growing in thermal spring overflow waters. Most of the communities were graminoid dominated (appendix A) and would be described as wet to moist meadows to marshes. Qualifying as swamp were sites with Salix spp., Betula glandulosa, or B. occidentalis dominant. More than half the plots had weedy or increaser species present and some plots were dominated (to the virtual exclusion of all other species) by introduced and/weedy species (for example Scholochloa festucacea, Poa pratensis, and Phleum pratense). Some of these communities were planted long ago as part of a management program to raise forage and show no evidence of replacement by native species through successional processes.

The dissemination of this weedy flora is a continuing and pervasive result of wildlife movements and disturbance. In addition, heavy ungulate use has kept Salix spp. populations hedged to heights generally not exceeding those of the 
graminoid layer: few plants produce catkins. It is not known if this intensity of browsing is detrimental to these willow populations.

\section{Conclusions}

We anticipate being able to reduce the diversity of com munity types (dominance types) to significantly fewer "site types" based on the similarity in their environments. Relatively recent findings in wetlands research indicates that the first species to colonize a site can preempt this site from competitor species equally suited to the site. Identification of dominant species with similar ecological amplitudes through species and community ordinations is our immediate objective. This analysis will result in a preliminary classification to be field tested in the summer of 1986.

\section{Literature Cited}

Cowardin, L. M., V. Carter, F. C. Golet, and E. T. LaRoe. 1979. Classification of wetland and deepwater habitats in the United States. Office of Biol. Serv., Fish and Wildlife Serv. Publ. FWS/OBS 79/31. 103 pp.

Daubenmire, R. 1959. A canopy-coverage method of vegetational analysis. Northwest Sci. 33:43-64.

Mattson, D. J. 1984. Classification and environmental relationships of wetland vegetation in central Yellowstone National Park, Wyoming. M.S. Thesis, Univ. of Idaho, Mascow. 409 pp.

Pierce, J. 1985. Wetland classification for west-central Montana. USDA-FS Northern Region Ecology Program, Unpub. Rept., 100 pp.

Steele, R., S. V. Cooper, D. M. Ondov, D. W. Roberts, and R. D. Pfister. 1983. Forest habitat types of eastern Idaho-western Wyoming. USDA-FS Gen. Tech. Rept. INT-144. 122 pp.

Stewart, R. W, and H. A. Kantrud. 1972. Vegetation of prairie potholes, North Dakota, in relation to quality of water and other environmental factors. U.S. Geol. Surv. Prof. Pap. 585-D. 36 pp.

Youngblood, A. P., W. G. Padgett, and A. H. Winward. 1985. Riparian community type classification of eastern Idaho-western Wyoming. USDA-FS Intermtn. Region R4-Ecol-85-01, Unpub. Rept. 152 pp.

\section{Appendix A}

Distribution of dominance types by class and subclass of the Palustrine system according to the national wetlands classification of Cowardin and others (1979). 
Class=Forest; Subclass=Broadleaved Deciduous: Dominance Types: Populus tremuloides, Populus angustifolia

Class=Scrub-scrub; Subclass=Broadleaved Deciduous: Dominance Types: Alnus incana, Betula glandulosa, Betula occidentalis, Salix wolfii, S. geyeriana, S. bebbiana, S. com mutata, S. myrtillifolia, S. candida, S. lemmonii, Potentilla fruticosa, Artemisia cana

Class=Emergent; Subclasses=Persistent and Nonpersistent: Dominance Types: Scirpus acutus, Typha latifolia, S. acutus-Triglochin maritimum, Carex rostrata, C. rostrata-Carex aquatilis, C. rostrata-Carex simulata, C. rostrata-Scholochloa festucaces, C. rostrata-Carex atherodes, C. aquatilis, C. simulata, C. atherodes, C. simulata-Juncus balticus, C. aquatilis J. balticus, C. aquatilis-Carex lanuginosa, C. aquatilis-C. simulata, Carex vesicaria, Carex lasiocarpa, Carex lanuginosa, Carex praegracilis, Carex nebrascensis, Carex unilateralis-Poa palustris, Juncus balticus, J. balticus-Bromus inermis, Poa palustris, Bromus inermis, Phleum pratense, Agrostis alba, A. alba-Trifolium repens, A. alba-Apocynum canabium, Beckmannia syzigachne-Glyceria striata, Deschampsia cespitosa, Eleocharis palustris, Eleocharis pauciflora, Eleocharis rostellata, Eleocharis acicularis, E. acicularis-Senecio hydrophilus, Equisetum laevigatum, Equisetum variegatur, Calamagrostis inexpansa, Aster chilensis, Trifolium repens, Helianthus nuttallii. 